\title{
IMPACT OF THE STATE REGULATION OVER INVESTMENT PROCESSES IN THE CONSTRUCTION SECTOR: FOREIGN EXPERIENCE AND POSIBILITY TO THE UKRAINE
}

\author{
Vasyl Dmitrenko ${ }^{1}$, Yury Prav ${ }^{2}$ \\ ${ }^{I}$ Ph.D. (Economics), Professor, Cherkasy Institute of Fire Safety named after the Heroes of Chernobyl, Cherkasy, \\ Ukraine, dmytrenkovi@ukr.net, ORCID : https://orcid.org/0000-0003-1860-418X \\ ${ }^{2}$ Ph.D. (Economics), Associate Professor of the Public Administration Department of the Educational and Scientific \\ Institute of International Relations and Social Sciences, Interregional Academy of Personnel Management, Kyiv, \\ Ukraine,e-mail:vsegda_prav@ukr.net
}

Citation:

Dmitrenko, V., \& Prav, Y. (2020). Impact of the state regulation over investment processes in the construction sector: foreign experience and posibility to the Ukraine. Economics, Finance and Management Review, (2), 91-97. https://doi.org/10.36690/2674-52082020-2-91

Received: April 22, 2020

Approved: May 28, 2020

Published: June 05, 2020

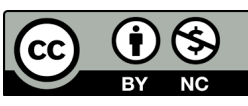

This article is an open access article distributed under the terms and conditions of the Creative Commons Attribution (CC BY-NC 4.0) license

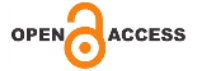

Abstract. The article examines the main areas of investment in the development of enterprises in the construction industry, which are used in different countries. The most developed countries such as the United States, Britain, Germany, France and China have been studied. Methods and tools of state regulation of the process of attracting investment in construction have been studied. The government of Great Britain is a supporter of attracting foreign direct investment to the country, which is accompanied by the introduction of advanced foreign technology and an increase in the number of jobs. German provides equal business conditions to foreign and national investors. German law does not impose any restrictions on the import and export of foreign capital, on the participation of foreigners in the capital of companies that are established or on the holding of senior positions by foreigners in such companies. The attitude of France to foreign investment is generally friendly although the government's position towards it is changing from time to time. Investment of foreign capital is not allowed, or it is limited only in certain sectors of the economy like subsoil exploration, mining or pharmaceutical industry. The main priorities of the USA investment policy are to attract investment to the country, as well as to stimulate foreign investment in order to create additional jobs and economic recovery. Thanks to foreign investment, China the issue of employment is solved, the transition to high-tech production is carried out, the economy is transitioning to a market format and becomes integrated into the world economy. The experience of attracting investment from foreign countries can be useful for the Ukrainian government.

Keywords: economic security, security management, enterprises in the construction industry, government management.

JEL Classification: E22, F50, R20

Formulas: 0; fig.: 0; tabl.: 0; bibl.: 10

Introduction. The state regulation of investment activity in Ukraine is an important component of the economic management system and a tool for implementing the investment policy of the state. Its main goal is to create conditions for dynamic, balanced social and economic development of Ukraine. Currently the construction industry is one of the most important areas of public administration in terms of its social orientation and investment capacity. Investment processes in the construction sector ensure the reproduction of fixed assets of individual economic entities, sectors of the national economy as a whole through new construction, expansion, reconstruction and technical re-equipment of existing enterprises. In the process of carrying out the production activities of construction companies, investment resources are transformed into fixed assets, and through participation in investment processes, the potential of the construction industry is realized in general. Reasoning for ways to attract investment, form effective mechanisms for the state 
regulation of investment activities in construction are among the important areas of research on investment issues.

Literature review. Scientists pay sufficient attention to the risks when investing in construction. The nature of investment risk was investigated in the works of the following scientists including Gaidis N.M., Dashko I.M., Emelyanov O.Y., Kret I.Z., Zayarna N.M., Lytvyn Z., Moiseenko I.P., Nepomnyashchy O.M., Reverchuk S.K., Reverchuk N.Y., Yablonska A.V. However, despite a significant number of scientific publications in the field of investment risk, there is no single state classification mechanism for investment risk management because investment risks differ by place of their origin, by a set of external and internal factors that affect the extent they emerge and so on.

Aims. The objective of the article is to single out and characterize factors of the state regulation over investment processes in the construction sector in foreign countries and to reason the specifics of their adaptation for the Ukrainian economy.

Methods. In the study, scientists used methods of theoretical analysis and content analysis, monographic method, method of systematization to identify and specify the author's position within the studied issues. When preparing conclusions and recommendations based on the results of the study, the method of generalization was used.

Results. A market economy operates on the basis of a free choice of priorities and investment directions. The construction industry will require an acute need in investment until there is economic motivation of investors and the financial benefits of investing in construction.

Sustainable development of the construction sector requires continuous improvement of applied approaches, taking into account both regional practice and foreign experience. Analysis of the experience of foreign countries in the state regulation and stimulation of investment activity in construction will help to develop a new, effective mechanisms for implementing the state policy in the field of housing, industrial and infrastructure construction, establishing and expanding international cooperation in construction, creating opportunities for investment in housing and industrial construction, including the foreign one.

We will consider foreign practice of the state regulation over investment and construction processes, which are relevant to borrowing or improvement in Ukraine, in such developed countries as the United States, Britain, Germany, France and in the largest country with the economy in transition which is China.

The government of Great Britain $[1 ; 2]$ is a supporter of attracting foreign direct investment to the country, which is accompanied by the introduction of advanced foreign technology and an increase in the number of jobs. The country has one of the most attractive investment regimes among developed countries.

Bilateral agreements between the United Kingdom and other countries on promoting and encouraging trade and investment and similar agreements operating within the European Union play a significant role in attracting foreign capital to the country. 
The basic legislative act regulating investment activities in the country is The Financial Services and Markets Act 2000 as amended.

The mechanism of currency control promotes the inflow of foreign investment in the UK. However, foreign firms set up to import and realization of the products on the London market that are created outside the "sterling area" must be financed solely at the expense of their own funds. However, if the company that is being established is of serious interest to the British economy, foreign investors can receive British loans to develop their business.

A clear and fairly simple system of business registration is introduced on the territory of the country, so that foreign investors are free to choose different objects for their investment.

A system of financial benefits, unified to domestic and foreign companies has been developed by the British government and it applies to investors.

The British investment activities are regulated by special bodies, most of which are independent self-regulatory organizations and authorized exchanges, and the state only provides the relevant regulatory framework. In particular, mutual investment trusts and open-ended investment companies effectively combine small investments into large ones.

A factor limiting the activities of foreign investors is the current system of taxation and currency restrictions. Recently there has been a tendency in the UK to take a more differentiated approaches to the assessment of investment expansion plans by individual foreign firms and to link them to specific commitments. The takeover of domestic firms by foreign capital is considered undesirable.

Foreign investments play a much more important role in the German economy $[1 ; 3 ; 4 ; 5]$ than in other European countries. The country provides equal business conditions to foreign and national investors. German law does not impose any restrictions on the import and export of foreign capital, on the participation of foreigners in the capital of companies that are established or on the holding of senior positions by foreigners in such companies. The country has a large number of enterprises with foreign participation, which actively use the scientific and technical achievements of the parent companies located abroad.

The Law on Credit Institutions, the Investment Companies Act regulate investment activities in the country. Investment companies are subject to control by The Federal Financial Supervisory Authority.

The direction of foreign investment is regulated by the taxation system.

The concept of "a social task", which corresponds to the concept of "a target program" is used in the practice of regional investment. Target rules for "Improving the regional economic structure" have been developed in the new (eastern) federal states. They helped stimulate investment by providing subsidies for infrastructure development from the federal and land budgets, as well as from the European Regional Development Fund.

The attitude of France $[1 ; 3 ; 6]$ to foreign investment is generally friendly although the government's position towards it is changing from time to time. 
Investment of foreign capital is not allowed or it is limited only in certain sectors of the economy like subsoil exploration, mining or pharmaceutical industry.

Relations in the investment sphere are regulated by the Code of Financial and Monetary System. No special permit is required to invest in France and to foreign countries from France. At the same time, the procedures provide for the submission of a declaration to the Ministry of Economy and Finance.

A foreign company is subject to the national regime of paying taxes, obtaining loans and various benefits. There are no restrictions on the transfer of funds of foreign investors from the country.

With the general liberal attitude to foreign investment, France introduces a number of restrictions on the rights of non-residents. First of all, this applies to foreign investment in certain industries like oil production, refining and import. In addition, foreign investors are not allowed to hold management positions in the companies engaged in these activities.

There are currency controls, as well as special controls directly related to currency restrictions on foreign loans, domestic and foreign direct investment in France.

In 1977, France adopted a circular on France's direct investment abroad and foreign direct investment in the country, which limits the excessive influence of foreign capital.

Relations between the state and the regions are built on a contractual basis within the national planning system. Each region concludes planned contracts with the state, which bind both parties to a specific investment program. Then they are included in the national plan of the state as a priority. At the same time, additional funds are allocated to the most problematic regions. The implementation of such a policy is carried out in a form of restructuring the economy of the regions. To this end, with the help of investment grants provided by the state, aid is provided to improve regional infrastructure and create jobs in priority sectors of the economy.

The main priorities of the American $[1 ; 3 ; 4 ; 7]$ investment policy are to attract investment to the United States, as well as to stimulate foreign investment in order to create additional jobs and economic recovery. In this regard, the main priority of the federal government, state and municipal authorities is the maximum support of potential investors and the creation of effective incentives for investment.

Relations in the investment sphere at the federal level are regulated by The Foreign Investment and National Security Public Act No. 110-49 of 2007 and relevant sectoral laws.

Regulation of investment activities is carried out at two levels, ie at the federal and at the state levels. General rules are established at the federal level stating that foreign investors must follow in the US market. The local governments of each US state adopt laws, regulating acts regarding business and entrepreneurship conditions for foreign investors on their territory. The federal government does not play an active role in determining goals of economic development of a particular region of the United States. 
The USA government provides a level playing field for foreign and domestic investors. Foreign investors are free to invest in most sectors of the US economy, as well as withdraw shareholder capital and profits. The country has created the most effective system of investor protection, which consists of three lines of defence, including the state, self-regulatory organizations of brokers and brokers themselves. This is probably one of the reasons why the stock market of this country is very efficient.

The state takes an active part in investment processes. The state accounts for more than $20 \%$ of the gross investment in the US economy, $12 \%$ of which is on investments from the federal budget. The state's influence on investment activities is exercised through such financial instruments as preferential income tax rates, accelerated depreciation policy, preferential bank lending, innovation grants, and so on.

The United States is purposefully developing international cooperation in the investment sphere. In 2013, actions were actively taken to create a Transatlantic Free Trade Area (TAFTA), or the Transatlantic Trade and Investment Partnership (TTIP) as a free trade area between the United States and the European Union.

The government of China $[1 ; 8]$, having begun to carry out economic reforms since 1978, pays great attention to attracting foreign capital to the country. Thanks to foreign investment, the issue of employment is solved, the transition to high-tech production is carried out, the economy is transitioning to a market format and becomes integrated into the world economy.

According to the current law, there are the following forms of investment in China, namely equity joint ventures, cooperative joint ventures, companies with $100 \%$ foreign capital, stock market operations.

In addition, the People's Republic of China has a regime of differentiation of foreign investment into the following categories, ie encouraged, those underway, limited, prohibited.

To ensure a favorable investment climate, the government established administrative and economic entities with preferential regimes, namely, special economic zones, zones of economic and technological development, free trade zones, zones of near-border economic cooperation, zones of scientific and technological development. In total, according to the latest data, more than 200 zones of preferential economic regime have been formed on the territory of the People's Republic of China. There are technology parks in some developed regions that accumulate investment flows to China. It is also allowed to create new enterprises on preferential terms based on the old ones, which are recognized as unprofitable and subject to disbandment.

Liberalization of Chinese investment legislation is taking place not only through the application of a special regime for foreign investors, but also through improved business conditions for domestic enterprises.

Lending to the China's economy is carried out through the banking system. The main types of lending are commercial and political lending. When it comes to commercial lending, interest rates on loans, as well as lending directions are formed 
on the basis of market principles. Political lending is designed to play a role of a main tool for implementing the state economic policy. To this end, three state-owned development banks have been established in China. The main source of funds for political lending is the state budget. To finance the most important structural projects in the economy, created mainly on a sectoral basis, budget funds and various forms of savings of citizens who are under the responsibility of the state are actively used [3; 9].

Analysis of housing financing systems in developed countries (the USA, England, Germany, France) shows that they are based on a variety of specialized financial institutions like construction and savings, mortgage companies, investment banks, credit unions, as well as several financial technologies including construction savings, mortgage lending, a certain combination of them both, public and private financing, as well as various mixed forms of public and private financing. In these countries, the state also has effective market instruments for the state regulation over investment processes through the markets of pledged, secondary loans using the state (or semi-state) financial institutions.

In the US, the process of providing mortgage loans by credit institutions to purchase housing by borrowers takes place in the primary market, and mortgage loans granted by a lender are sold to an investor in the secondary mortgage market (they are refinanced by them). The proceeds are put back into circulation (granting new loans) by mortgage companies, and their profit consists of fees for loans granted and payments for their service. This model assumes the presence of a developed secondary mortgage market, which sells already issued mortgages. The model is attractive because it solves the problem of long-term financial resources. Construction and savings banks create the basis of the primary market of residential mortgage system in Germany and France. The nature of financial assistance for construction savings is that the future developer of housing accumulates a certain amount of money in the deposit account for several years under agreement with a construction bank. Subject to fulfillment terms of the agreement, in addition to the accumulated deposit and interest thereon, the depositor is entitled to receive a bank loan in an amount approximately equal to the amount of the accumulated deposit. Combining of three sources of money, ie of the developer's own deposit, a bank loan and the state assistance (premiums) allows the developer not only to start but also to complete a construction project. The construction savings system is autonomous, ie it does not require external borrowing. This distinctive feature is achieved by the fact that the time of using money, for example, of a participant A by other participants is equivalent to the time during which the latter uses other people's money himself.

The independence of the system from the financial market makes it possible to issue loans to participants at a rate below the market one, while government subsidies allow target savings to successfully compete with market instruments. The state realizes its own interests through the system of construction savings, namely forms a private housing stock, primary and secondary housing markets, reduces allocations for the operation and repair of public housing, solves the major social problem of housing [10]. 
The building society system is successfully operating in the UK. The mechanism of their work is somewhat similar to the activities in Germany, but it is not necessary to be a depositor of a construction company to obtain a housing loan. Recently as a result of the liberalization of British banking legislation, functions of these companies are becoming more similar to those of commercial banks. The competition of the above entities leads to their convergence and reduction of credit rates [1].

Summarizing the above, it should be noted that the activities of foreign investors in foreign countries are regulated by national law. There are no special laws or codes for foreign investment, only some administrative regulations have been developed, as well as related articles of certain laws. The legislation is mainly aimed at liberalizing the investment regime and providing foreign investors with no less favorable conditions than domestic ones; guarantees for the transfer of profits, and a full compensation in case of expropriation of their property; opportunities to resolve disputes between a foreign investor and the host country that receives investments.

Conclusions. In general, the policy of foreign countries in the investment sphere pursues the main goals as follows:

- directing investments to restructure the economy to increase its efficiency;

- turnover of savings in investments of the real sector of the economy;

- formation of an efficient and controlled capital market;

- reduction and insurance of investment risks;

- improving the investment climate for domestic and foreign capital.

\section{References:}

1. Buhrynets, R.A. (2009), "Regulation of foreign direct investment in some countries", Visnyk Donetskoho natsionalnoho universytetu. Ser. V: Ekonomika i pravo, №1, pp. 360-365.

2. "Financial Ukraine" is an information and analytical portal of the Ukrainian Financial Development Agency (2020), retrieved from: http://www.ufin.com.ua/index.htm.

3. Isaienko, D. (2011), "Housing construction abroad: experience for Ukraine", Publichne upravlinnia: teoriia ta praktyka, №3(7), pp. 146-151.

4. Rakhman, Y.A. (2001), "Foreign experience in regulating investment and construction activities", Эkonomyka stroytelstva, №6, pp. 45-52.

5. Investment funds and the investment mechanism in Germany (2020), retrieved from: http://www.ereport.ru/articles/finance/geinvest.htm.

6. Bulhakov, Y. Kazantsev, S.V. and Fynkel, S.M. (2003), Ynvestytsyonnoe obespechenye эkonomycheskoho razvytyia: kapytal, vlozhenyia, stroytelnbii kompleks, proektyrovanye [Investment support of economic development: capital, investments, construction complex, design], VO «Nauka», Novosibirsk, Russia, 186 p.

7. Investment policy USA (2016), retrieved from: http://www.ufin.com.ua/index.htm.

8. Investing in China. Forms of investment (2015), retrieved from: http://vchae.com/investitsii-vkitay-formi-investicii/.

9. Turekulova, A.B. (2015), "State regulation of investment activity: the experience of foreign countries", retrieved from: http://www. rusnauka. com/16_EI SN_2015/Economics/15_194308.doc.htm.

10. Corporate governance in the system of economic security of joint stock companies of Ukraine (Denisenko M.P., etc.), 2012 (Ukrainain). 